\title{
Просторова диспозиція агентів комунікації в соціальних мережах
}

\author{
Дідик Л. А., Національний педагогічний університет імені М. П. Драгоманова
}

Проведено аналіз досліджень та публікацій науковців щодо визначення поняття «соціальна мережа» та запропоновано власне трактування даного поняття. Автор статті вважає, що соціальна мережа - це коло агентів (людей), де самі агенти є центрами соціальних мереж, а їхні знайомі (зв'язки) будують мережеві гілки, вступаючи у соціальні відносини. Встановлено особливості мережевої комунікації: об'єднання «багато 3 багатьма»; емерджентні властивості (відсутність централізованого управління, самостійність та високий рівень підключеності субодиниць, павутинна нелінійність впливу один на одного); динаміка в поведінці мережі; отримання і створення соціального капіталу. 3'ясовано, що соціальний капітал $є$ основним джерелом розвитку соціальних мереж, оскільки він може проявляти себе в якості особливого виду реальних і потенційних ресурсів; властивостей та інформаційної спрямованості мережі. Охарактеризовано загальносистемні закономірності розвитку соціальних мереж: різноманітність, складність, поширеність, стійкість, емерджентність як неможливість звести сукупність властивостей системи до властивостей окремих елементів та їх неідентичність. Визначено стрімкий розвиток комерційної складової соціальних мереж створення професійних співтовариств і мереж практиків, які знайшли застосування в багатьох областях людської діяльності у сучасному світі. Проаналізовано причини, які впливають на зміну форм взаємодії агентів комунікації, та висловлено власну думку, що вони змінюються в ході задоволення агентами базових просторових потреб: комунікативної, пізнавальної, ігрової. Визначено, що в Україні соціальні мережі почали набирати популярності з 2006 р. - доступ до Одноклассники.ru, ВКонтакте.ru та Connect.ua. $32015-$ 2016 pp. - етап популярності Facebook.com (11 млн користувачів) та Instagram.com (7,3 млн користувачів), що пов'язано з політичними змінами у відносинах між Україною та Росією. Проаналізовано інформацію щомісячного дослідження Kantar TNS CMeter та визначено, що у 2018 p. Facebook.com знаходиться на третьому місці по відвідуваності серед популярних сайтів, якими користуються українці.

Ключові слова: інтернет; мережева комунікація; комунікативний простір; соціальний капітал; інтернет-технології; соціально-мережеві технології

\section{Spatial disposition of agents of communication in social networks}

\section{Didyk L.A., National Pedagogical Dragomanov University}

Author analyzed researches and publications of scientists on the definition of the concept «social network» and proposed own interpretation of this concept. Author of this article thinks that social network is the circle of the agents (people) where the agents are centers of social networks and their familiar (communications) build network branches entering into social relations. Features of the network communication were established: union «many with many»; emergent properties (absence of centralized control, independence and subunit's high level of connectivity, spiderweb's non-linearity of the influences for each other; dynamics in behavior in social network; receiving and creation of the social capital. Found the social capital is a main source of the social networks 'development because can show itself as a special kind of the real and potential resources; properties and network's information direction. Characterized system-wide patterns of social networks` development: diversity, complexity, prevalence, persistence, emergence as impossibility to reduce totality of the system to properties of the separate properties and their non-identity. And identified sweeping development of the social network's commercial constituent,-creation of the professional commonwealths and practices networks that have found application of many directions human activity in modern world. In this article author analyzed causes that affect the change of forms communication agents' interaction and tell own opinion they change in progress of satisfaction the base spatial needs: communicative, informative, game. Spot that in Ukraine social networks start to gain popularity since 2006-access to Odnoklassniki. ru,VKontakte.ru and Coonect.ua. Stage of popularity Facebook.com (11 millions users) and Instagram (7,3 millions users) since 2015-2016 which is connected with political changes in a relationship between Ukraine and Russia. Analyzed information of monthly study Kantar TNS CMeter and defined that in 2018 Facebook.com became on the third place in attendance among popular sites which are used by Ukrainians.

Keywords: Internet; network communication; communicative space; social capital; internet technologies; social networking technologies 


\section{Пространственная диспозиция агентов коммуникации в социальных сетях}

\section{Дидык Л. А., Национальный педагогический университет имени М. П. Драгоманова}

Проведен анализ исследований и публикаций ученых относительно определения понятия «социальная сеть» и предложено собственную трактовку данного понятия. Автор статьи считает, что социальная сеть это круг агентов (людей), где агенты являются центрами социальных сетей, а их знакомые (связи) строят сетевые ветви, вступая в социальные отношения. Установлены особенности сетевой коммуникации: объединение «много со многими»; эмерджентные свойства (отсутствие централизованного управления, самостоятельность и высокий уровень подключенности субъединиц, паутинная нелинейность влияния друг на друга); динамики в поведении сети; получение и создание социального капитала. Выяснено, что социальный капитал является основным источником развития социальных сетей, так как может проявлять себя в качестве особого вида реальных и потенциальных ресурсов; свойств и информационной направленности сети. Охарактеризовано общесистемные закономерности развития социальных сетей: разнообразие, сложность, распространенность, устойчивость, эмерджентность как невозможность свести совокупность свойств системы к свойствам отдельных элементов и их идентичность. Определено стремительное развитие коммерческой составляющей социальных сетей - создание профессиональных сообществ и сетей практиков, которые нашли применение во многих областях человеческой деятельности в современном мире. В статье проанализировано причины, влияющие на изменение форм взаимодействия агентов коммуникации и сформулировано собственное мнение, что они меняются в ходе удовлетворения агентами базовых пространственных потребностей: коммуникативной, познавательной, игровой. Определено, что в Украине социальные сети начали набирать популярность с 2006 г. - доступ к Одноклассники.ru, ВКонтакте.ru и Connect.ua. C 20152016 гг. - этап популярности Facebook.com (11 млн пользователей) и Instagram.com (7,3 млн пользователей), что связано с политическими изменениями в отношениях между Украиной и Россией. Проанализирована информация ежемесячного исследования Kantar TNS CMeter и определено, что в 2018 г. Facebook.com находится на третьем месте по посещаемости среди популярных сайтов, которыми пользуются украинцы.

Ключевые слова: интернет; сетевая коммуникация; коммуникативное пространство; социальный капитал; интернет-технологии; социально-сетевые технологии

\section{Постановка проблеми.}

$\mathrm{M}$ ережеві комунікації мають ряд властивостей та особливостей, які виділяють їх серед інших типів комунікації. Основною властивістю комунікаційної мережі, як і будь-якої мережі, є багатоканальність, висока щільність логістичних шляхів переміщення інформації. Якщо одна ланка випадає 3 мережі, комунікація легко знаходить інші шляхи, альтернативні ланцюжки комунікаційних ланок. Потенційна можливість здійснення комунікації кожним, забезпеченим технічними можливостями комп'ютерних телекомунікацій, без обмеження в часі i просторі, а також індивідуальної чи групової комунікації, в залежності від використовуваних програмних засобів (інтернет-технологій), традиційно вважається однією з відмінних рис мережевої комунікації. Вважається, що мережева комунікація, як гібрид, отриманий в результаті схрещування індивідуальної, групової та масової комунікації, має характерні риси цих видів комунікації. У статті розглядаємо дану позицію з точки зору соціологічного аналізу.

Аналіз досліджень і публікацій.

Поняття «соціальна мережа» було введено у світову науку в 1954 році англійським соціологом
Дж. Барнсом. Автор цим поняттям охарактеризовує суспільство, яке являє собою розгалуження людських соціокомунікативних відносин. Вперше Дж. Барнсом було досліджено соціокомунікативні зв'язки між членами суспільства і відображено ці зв' язки на спеціальних геометричних схемах-діаграмах, які візуалізували ці відносини за допомогою ліній і крапок, де крапки - це громадяни суспільства, а лінії - це соіокомунікативні відносини між ними.

Термін «Virtual Community» (віртуальне, або мережене суспільство) та його значення розробив Г. Рейнгольд: «Віртуальні співтовариства $€$ соціальними об'єднаннями, які виростають 3 мережі, коли група людей підтримує відкрите обговорення достатньо довго і людяно, для того щоб сформувати мережу особистих відносин у кіберпросторі» [4].

Сучаснї теорії соціальних мереж були вперше запропоновані в 1951 році Р. Соломонофф і А. Рапопорт. У 1959-1968 рр. угорські математики П. Ердос і А.Рен’ї написали вісім статей, що описують принципи формування соціальних мереж [4].

Список науковців, яких цікавили і цікавлять теми віртуальних соціокомунікативних відносин, доволі значний. Соціокомунікативні відносини за- 
клали базис розвитку інформаційного суспільства, а інтернет - віртуалізував ці відносини і зв'язки, перетворивши користувачів соціальних мереж на своєрідних віртуальних агентів. Мова йде про таких видатних науковців у питаннях вивчення глобальної мережі та, зокрема, ролі соціальних віртуальних мереж: Дж. Барнс, Е. Ботт, К. Мітчелл, А. Редкліф-Браун, А. Сфремов, А. Федонюк, В. Сазанов, В. Горовий, С. Цимбаленко, С. Водолазька та інші.

На початку XXI століття поняття «соціальна мережа» набуває значної актуальності, варто детальніше розглянути його визначення. Соціолог В. Сазонов соціальну мережу трактує як «безліч акторів (агентів), які можуть вступати у взаємодію одне 3 одним і зв'язки між якими є соціальними» [12]. Загалом, соціальні мережі у сучасному розумінні - це віртуальні сайти, які є легкодоступні і зрозумілі у використанні, вони створюють певне віртуальне співтовариство людей за їх інтересами. На таких сайтах зазвичай є багато реальних акаунтів, але також є і фейкові (несправжні, вигадані) акаунти.

Історія створення соціальної мережі датується 1971 р. і вважається роком, коли було відправлено перше повідомлення на віддалений комп'ютер першим користувачам військової соціальної мережі Arpanet. Це була перша у світі віртуальна комунікація, яка дозволила створити дискусійні форуми, поштові розсилки та налаштувала перший інтернаціональний зв'язок 3 Лондоном та Норвегією. Двома наступними етапами розвитку ери соціальних мереж стали: 1) винахід IRC (англ. Internet Relay Chat - ретранслюється інтернет-чат) - сервісної системи для спілкування в режимі реального часу, яка була створена в 1988 р. фінським студентом Я. Ойкаріненом; 2) 7 серпня 1991 британський вчений Т.Бернерс-Лі вперше опублікував перші інтернет-сторінки [15].

Поява наближеної до сучасних соціальних мереж датується 1995 роком із часу створення в США під авторством Р. Конрадса сайту Classmest.com, цей портал започаткував створення наступних характерних веб-проектів. Сучасні вчені-соціологи вважають, що ера соціальних мереж розпочалася орієнтовно у 2003 або 2004 роках, у період формування сучасних популярних соціальних мереж Facebook.com (2004), MySpace.com (2003) та LinkedIn.com (2003). В Україні соціальні мережі почали набирати популярність із 2006 року, коли на український інтернет-простір зайшли перші російські соціальні мережі Одноклассники. ru та ВКонтакте.ru, у грудні 2007 року був ство- рений Connect.ua - український сайт знайомств як «соціальна мережа знайомств», але пізніше переорієнтований виключно на знайомства. Проте, починаючи з періоду політичних змін та відносин між Україною та Росією, російські соціальні мережі втрачають свою популярність в Україні, а от американський Facebook.com, Instagram.com, навпаки, починає набирати популярності (з 20152016 рр.).

Таким чином, вивчивши історію виникнення соціальних мереж та визначення, які дають науковці даному поняттю, можемо запропонувати власне розуміння та трактування терміну. Соціальна мережа - це коло агентів (людей), де самі агенти є центрами соціальних мереж, а їхні знайомі (зв'язки) будують мережеві гілки, вступаючи у соціальні відносини.

\section{Виклад основного матеріалу.}

Виділяють ряд характерних особливостей сучасної комунікації, опосередкованої соціально-мережевими технологіями: віртуальність, інтерактивність, гіпертекстуальність, глобальність, оперативність, системність, креативність, анонімність, мозаїчність [7]. У віртуальному контексті відбувається переплетення двох зустрічних інноваційних процесів: 3 одного боку, спостерігається все більша символізація соціальної реальності, $з$ іншого - в результаті розвитку техніки виникло особливе технічне віртуальне середовище, що, в свою чергу, спричинило перетворення «віртуальності» соціальних форм у форми технічної віртуальності.

Основою поняття гіпертекстуальності є уявлення про гіпертекст, який володіє певною динамікою, тому що дозволяє користувачеві самому моделювати і організовувати текстовий простір зручним для самого користувача чином. У обговорюваній нами темі гіпертекстуальність трактується як багатозначність, полідискурсивність, багатоголосся віртуального спілкування. В. Сазонов пропонує наступну характеристику мережевої комунікації: перша особливість соціальних мереж - комбінаторна, топологічна організація внутрішньомережевої міжособистісної взаємодії 3 комунікаційної точки зору, оцінює потужність об’єднання «багато з багатьма». Тоді як у класичній трансляційній мережі «один до багатьох» (зборів, радіо і ТБ, проповідь) потужність $є$ пропорційною числу точок (учасників). У схемі, електронної пошти (транзакційної), 3 двостороннім спілкуванням «один до одного».

Другою особливістю соціально орієнтованих мережевих об'єднань є їх емерджентні власти- 
вості. Зокрема, «районові ефекти»: відсутність централізованого управління; самостійність та високий рівень підключеності субодиниць; павутинна нелінійність впливу один на одного.

Третьою особливістю є групова динаміки в поведінці мережі, формування кластерів різного розміру і зміна структури в часі [12].

Найбільш важливою характеристикою мережевої комунікації, на думку дослідника О. Лещенка, «є отримання і створення соціального капіталу за допомогою функціонування соціальної мережі. Це обумовлено тим, що факт створення, функціонування соціальної мережі визначається потребою в накопиченні соціального капіталу» [2].

Соціальний капітал зумовлює форми мережевої комунікації, тому що потреби, цілі і мотиви учасників комунікації впливають на іiі інформаційний напрямок, а властивість причетності соціальної мережі, що розкриває динаміку інформаційних потоків, і потенційна нескінченність зростання системи (в основі якої лежить, в тому числі і «егоїстична селекція», i анонімність, і т.д.), іiі емерджентність підсилюють даний ефект [2].

O. Лещенко визначає соціальні мережі як структурну основу соціального капіталу. Соціальна мережа як явище, що володіє об'єктивною предметністю, являє собою сукупність соціальних взаємин і соціальних зв'язків між певними індивідами і самих індивідів, що дозволяють обмінюватися різними видами нематеріальних ресурсів, в тому числі інформаційних, в процесі їх взаємодії [2].

У цьому сенсі Р. Роуз розглядає соціальний капітал як сукупність формальних і неформальних соціальних мереж, які індивіди використовують для виробництва або розподілу товарів і послуг, що підтверджує - соціальний капітал виникає у відносинах між індивідами [11].

Соціальні мережі в цьому розумінні виконують багатофункціональну роль: реалізують спільні інтереси домогосподарств та індивідів, організовують спільні види діяльності домогосподарств та індивідів, шукають інформацію, яка пов'язана 3 місцезнаходженням людей, тварин, предметів і т. д. У перспективі соціальні мережі стануть звичним атрибутом соціального життя, комунікацій сучасного суспільства. Вони повинні будуть бу- дуватися за цілком певними ознаками: контакти, спілкування, професія.

На підставі цього ми бачимо, що соціальний капітал служить джерелом розвитку мережі і нерозривно пов'язаний з іiі функціонуванням, тому що він може проявляти себе в якості особливого виду реальних і потенційних ресурсів; властивостей та інформаційної спрямованості мережі (види соціального капіталу, які визначають вид соціальної мережі - контакти, професійні і т.д.).

Соціальні мережі, в основі яких лежить мобілізація соціального капіталу та його створення, $є$ мережами з горизонтальними зв' язками ${ }^{1}$, без вертикальної осі координат, в яких переважають слабкі зв'язки, а також збудовані навколо універсальні норми та цінності. «Спонтанне спілкування», яке підтримує мережу слабких зв'язків, є головною цінністю в таких мережах [13].

Інструменти пошуку потрібних контактів та встановлення зв'язків між людьми являються головною особливістю соціальних мереж. Інструменти соціальної мережі дають змогу користувачеві створити свій віртуальний портрет - вказуючи докладно дані про себе, свій досвід роботи, захоплення, інтереси і цілі, сформувати профайл. Інші учасники мають змогу знайти акаунт користувача за цією інформацією. Існування профайла дає змогу користуватися механізмами пошуку людей, спілкування з якими необхідне по роботі та навчанні, однодумців, одновірців, колег. Крім цього, існують соціальні мережі, що допомагають шукати не тільки людей за інтересами, а й безпосередньо самі об'єкти цих інтересів: веб-сайти, улюблена музика і т. д. 3 цієї точки зору, соціальні мережі виконують функцію створення індивідуальних профілів, в яких міститься відповідна інформація про користувача, інтерактивне спілкування між користувачами (використовуючи перегляди профайлів користувачів один одним, внутрішньої пошти, коментарів та ін.), можливість кооперації для досягнення спільної мети (наприклад, метою соціальної мережі може бути ведення групового блогу, пошук нових друзів, однодумців та ін.). Крім того, агенти комунікацій в соціальних мережах $є$ не лише споживачами нової інформації, а й активними іiі творцями, що впливає на соціаліза-

${ }^{1}$ Міркування Г. Патнема полягають в тому, що спільноти, засновані на регіонально-етнічному або релігійному базисі стають більш згуртованими, збільшуючи внутрішньогрупову згуртованість, а разом із нею - відстань між групою і рештою суспільства. У якийсь момент концентрація ресурсів всередині спільноти стає настільки високою, що їх мобілізація більш доцільна, ніж звернення за ресурсами в офіційні інститути. В цьому випадку група інституціоналізується, стає кримінальною, формує свої органи управління та охорони правопорядку. При цьому слабкі зв'язки витісняються сильними, в той час як контакти поза групою зводяться до мінімуму. Г. Патнем уточнює, що ці інститути вибудовують мережу навколо партикулярних, а не універсальних норм і цінностей. Вони також змушені формувати свою ієрархію, їх внутрішню мережу зв'язків не можна назвати горизонтальною. 
цію, взаємодію індивідів і цілих спільнот в інтернет-просторі. I тут можемо прослідкувати вияв космополітизму, коли людина легко знаходить доступ до різноманітного контенту, знаходиться в курсі подій з цілого світу.

3 точки зору В. Сазонова, «прогнозований шлях розвитку - це поділ сфер впливу на мережі спілкування і знайомств, особистих і ділових контактів, професійні мережі, соціально-орієнтовані проекти» [13]. Розглядаючи соціальну мережу як універсум, який включає психологічні, соціальні та технічні компоненти, буде корисним визнати такі загальносистемні закономірності: різноманітність, складність, поширеність, стійкість, емерджентність як неможливість звести сукупність властивостей системи до властивостей окремих елементів та їх неідентичність. Крім побудованих, як правило, на комерційній основі розвинених масових ностальгічних соціальних мереж, технології соціальних мереж розвивалися в напрямку створення професійних співтовариств і мереж практиків, які знайшли застосування в багатьох областях людської діяльності у сучасному світі. Саме цей розвиток соціальних мереж змінює підходи до пошуку, обробки та поширення інформації, створюючи нові способи взаємодії 3 аудиторією та в цілому впливаючи на світову економіку і політику.

На даний момент, на думку С. Бондаренко, можна спостерігати три види або класи соціальних мереж, а саме: комерційні, орієнтовані на прибуток; мережі, практиків, навчання; соціально-значущі проекти [13].

Наразі, можемо спостерігати виникнення все нових і нових соціальних мереж, зокрема унікальних нішевих об'єднань (наприклад, для науковців, для лікарів, для школярів, для інвалідів, любителів собак і т. д.), які з часом знайдуть своїх лояльних користувачів і займуть своє місце на ринку. Таким чином, ринок соціальних мереж наповнюється, що підвищує конкуренцію між ними і спонукає до інновацій. У випадку соціальних мереж - це виникнення нових функцій, додатків. Прикладом успішного додатку, який переріс у самодостатню соціальну мережу є Instagram.com. В Україні 7,3 млн користуються Instagram.com, 11 млн є користувачами Facebook.com. Єдиною соціальної мережею, яка входить у ТОП-10 популярних серед українців сайтів залишається Facebook.com. Згідно $з$ результатами дослідження Kantar TNS CMeter станом на квітень 2018p. Facebook.com знаходиться на третьому місці по відвідуваності [5; 9].

Отже, форми мережевої комунікації залежать від геометричної конфігурації соціальних акторів, тобто співвідношення домінантності та комунікативності в соціомережевих структурах, від інформаційної змістовності, тобто професійні, дружні i т. д. Основними критеріями класифікації форм комунікації також $€$ :

- ступінь інтерактивності: on-line (IRC, ICQ) i off-line (листування по e-mail, список розсилки, телеконференція);

- спрямованості комунікації (моно- діа- i полілогічне);

- ступеня відкритості (авторизовані і корпоративні, публічні і приватні);

- стилю (ігрове і довірче).

Розглядаючи просторову диспозицію агентів комунікації в соціальних мережах, ми виходимо 3 пріоритету мотивації агентів, що беруть участь у мережевих комунікаціях, їхнього інтересу до здійснення соціальних практик в кіберпросторі та форм комунікації. Для того, щоб зрозуміти як змінюється просторова форма поведінки агентів комунікації в соціальних мережах, розглянемо ряд аргументів та причин (див. табл. 1). 
Таблиия 1. Причини поведінки агентів комунікації в соціальних мережах*

\begin{tabular}{|c|c|c|}
\hline Причини & Трактування & Автор \\
\hline $\begin{array}{l}\text { Нейробіологічні } \\
\text { причини }\end{array}$ & $\begin{array}{l}\text { Нормальна життєдіяльність вимагає припливу із зовнішнього } \\
\text { середовища речовини, енергії та інформації, що } \\
\text { підтверджують експерименти, які свідчать про драматичні } \\
\text { наслідки «інформаційного голоду» для мозку, що } \\
\text { розвивається. }\end{array}$ & П. Симонов \\
\hline $\begin{array}{l}\text { Участь у } \\
\text { реальних } \\
\text { комунікативних } \\
\text { практиках }\end{array}$ & $\begin{array}{l}\text { Феномен «віртуальних об’єднань» - це спрага до } \\
\text { спілкування, яке посилюється серед людей всюди у міру } \\
\text { того, як } 3 \text { нашого реального життя зникають неформальні } \\
\text { громадські простори. }\end{array}$ & Г. Рейнгольд \\
\hline $\begin{array}{l}\text { Взаємодія } 3 \\
\text { новими акторами }\end{array}$ & $\begin{array}{l}\text { Мережа компенсує процес атомізації суспільства, включає } \\
\text { генетичну пам’ять про початковий соціум, поміщає людину у } \\
\text { віртуальну мережеву группу, вписуючись у генетичний код } \\
\text { суспільства. }\end{array}$ & А. Ваганов \\
\hline Метафізичність & $\begin{array}{l}\text { Опосередковані людські інтеракції є вищим сенсом взаємодії } \\
\text { в соціальних мережах. }\end{array}$ & М. Хайм \\
\hline Креативнісь & 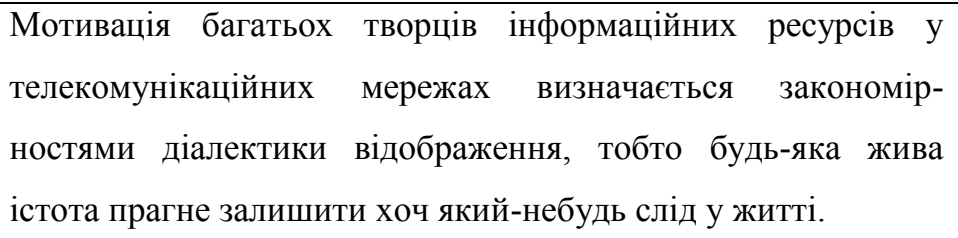 & О. Якимчук \\
\hline $\begin{array}{l}\text { Віра людини в } \\
\text { ессенціальне }\end{array}$ & 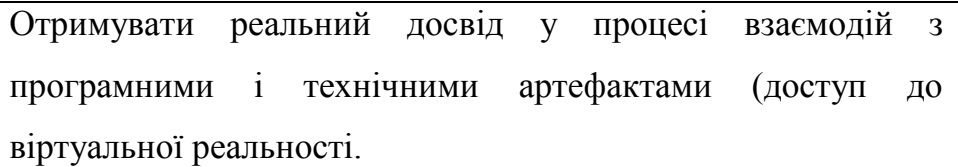 & В. Розін \\
\hline
\end{tabular}

* складено автором за матеріалами $[3 ; 10 ; 14 ; 15]$.

Проаналізувавши наведені у таблиці аргументи та причини просторової форми поведінки агентів комунікації в соціальних мережах, можемо зауважити свою думку, що форма мережевої комунікації залежить і змінюється в ході задоволення агентами базових просторових потреб: по-перше, комунікативної (внутрішня пошта, миттєві повідомлення, онлайн-конференції, групи, форуми, чати); по-друге, пізнавальної (пошук конкретної інформації, знайомство 3 новинами тощо); по-трете, ігрової (знайомства, розваги).

Таким чином, соціальна мережа являє собою особливий симбіоз соціальних та технічних ін- струментаріїв. При цьому необхідним засобом вирішення соціальних завдань мережі виступає iï технічне, програмне забезпечення. 3 цієї точки зору є доцільним визначити соціальні мережі як особливу, специфічну, конкретну форму соціально-орієнтованих інтернет-технологій.

Аксіологічний статус соціальних мереж полягає в тому, що вони виступають механізмом конструювання сучасного комунікативного простору сучасного суспільства за рахунок накопичення i реалізації особистого та соціального капіталу i дифузії інновацій, які охоплюють освітню, науково-інноваційну, політичну та економічну сфери сучасного суспільства [6]. 
Соціальний капітал нерозривно пов'язаний із функціонуванням мережі та служить джерелом iii розвитку. Ми можемо визначити отримання та створення соціального капіталу за допомогою функціонування соціальної мережі як найбільш важливу характеристику мережевої комунікації.

\section{Висновки.}

Підсумовуючи вищесказане, можемо зробити висновки, що на сьогоднішній день в інтернет-просторі створені сприятливі умови для розвитку мережевої комунікації, появи нових соціальних мереж, прояву комерційної складової у комунікаційній взаємодії агентів соціальних мереж, де можна спробувати все дозволене і заборонене без особливого законного чи морального контролю. Мережева комунікація швидкими темпами витісняє «старі» типи комунікації (на- приклад, живе спілкування, традиційне класичне листування, телеграми тощо), оскільки ії функціональні можливості дають перевагу у вирішенні та задоволенні базових просторових потреб людей: комунікаційні, пізнавальні, ігрові. Просторова диспозиція агентів комунікації в соціальних мережах прямо залежить від змін на ринку соціальних мереж. 3 появою все нових і нових мережевих об'єднань, зокрема унікальних нішевих (для науковців, лікарів, школярів, інвалідів, любителів собак і т.д.), та під впливом геометричної конфігурації соціальних акторів (ступеня інтерактивності, спрямованості комунікації, відкритості, стилю) форма мережевої комунікації набуває адаптивного характеру, що дозволяє слідувати вимогам сучасного життя, сприяє швидкому оволодінню інформації та інтегрованому вирішенні питань.

\section{БІБІЛІОГРАФІЧНІ ПОСИЛАННЯ}

1. Білан Н. І. Особливості соціальних мереж в інформаційному суспільстві / Н. І. Білан // Інформаційне суспільство. - 2015. - № 21. - С. 86-90.

2. Бурдье П. Социология политики / П. Бурдье. - М.: SOCIO-LOGOS, 1993. - 336 c.

3. Ваганов А. Г. Краткая феноменология Всемирной Паутины / А. Г. Ваганов // Общество и книга: от Гутенберга до Интернета. - М.: Традиция, 2000. - С. 42-53.

4. Данько Ю. А. Соціальні мережі як форма сучасної комунікації: плюси і мінуси / Ю. А. Данько // Сучасне суспільство. - 2012. - № 2. - С. 179-184.

5. Дзюбіна O. I. Комунікативний аспект соціальних мереж Facebook i Twitter / O. I. Дзюбіна // Вісник Дніпропетровського університету імені Альфреда Нобеля. Серія «Філологічні науки». - 2016. - № 2. - С. 218-222.

6. Курбан О. В. Класифікація соціальних мережевих технологій як PR-інструментів / O. В. Курбан // Інформаційне суспільство. - 2013. - № 17. - С. 41-43.

7. Михайлов В. А. Особенности развития информационно-коммуникативной среды современного общества / В. А. Михайлов, С. В. Михайлов // Актуальные проблемы теории коммуникации: сб. научн. тр. - СПб.: Изд-во СПбГПУ, 2004. - С. 34-52.

8. Назарчук А. В. Сетевое общество и его философское осмысление / А. В. Назарчук // Вопросы философии. 2008. - № 7. - С. 61-75.

9. Рейтинг популярних сайтів за квітень 2018. - Режим доступу: https:/tnsua.com/news/ reyting-populyarnih-saytivza-kviten-2018

10. Розин В. М. Понятие и современные концепции техники / В. М. Розин. - М.: ИФРАН, 2006. -255 с.

11. Роуз Р. Достижение целей в квазисовременном обществе: социальные сети в России / Р. Роуз // Общественные науки и современность. - 2002. - № 3. - С. 23-38.

12. Сазонов В. М. Социальные сети - анализ и перспективы / В. М. Сазонов. - Режим доступа: http://spkurdyumov. ru/biology/socialnye-seti-analiz-i-perspektivy/

13. Сазонов В. М. Социально-сетевые технологии. Системный анализ.и прогноз / В. М. Сазонов. - М.: Лаборатория СВМ, 2010. $-180 \mathrm{c}$.

14. Симонов П. В. Созидающий мозг: нейробиологические основы творчества. - М.: Наука, 1993. - 112 с.

15. Якимчук О. Агенти соціальних перетворень та причини розвитку онлайнових соціальних структур / О. Якимчук // Релігія та соціум. - 2012. - № 2. - С. 178-184. 


\section{REFERENCES}

1. Bilan, N.I. (2015). Osoblivosti sotsialnikh merezh v informatsiynomu suspilstvi [Features of social networks in the information society]. Informatsiyne suspilstvo, (pp. 86-90) [in Ukrainian].

2. Burde, P. (1993). Sotsiologiya politiki [Sociology of politics]. Moscow: Yzd-vo «SOCIO-LOGOS» [in Russian]. 3. Vaganov, A.G. (2000). Kratkaya fenomenologiya Vsemirnoy Pautiny [Brief phenomenology of the World Wide Web]. Obshchestvo i kniga: ot Gutenberga do Interneta, (pp. 42-53) [in Ukrainian].

4. Danko, Yu.A. (2012). Sotsialni merezhi yak forma suchasnoï komunikatsiï: plyusi i minusi [Social networks as a form of modern communication: the pros and cons]. Suchasne suspilstvo, 2, 179-184 [in Ukrainian].

5. Dzyubina, O.I. (2016). Komunikativniy aspekt sotsialnikh merezh Facebook i Twitter [The communicative aspect of social networks Facebook and Twitter]. Visnik Dnipropetrovskogo universitetu imeni Alfreda Nobelya. Seriya «Filologichni nauki», 2, 218-222 [in Ukrainian].

6. Kurban, O.V. (2013). Klasifikatsiya sotsialnikh merezhevikh tekhnologiy yak PR-instrumentiv [Classification of social network technologies as PR-tools]. Informatsiyne suspilstvo, 17, 41-43 [in Ukrainian].

7. Mikhaylov, V.A., \& Mikhaylov, S.V. Osobennosti razvitiya informatsionno-kommunikativnoy sredy sovremennogo obshchestva [Features of the development of the information and communication environment of modern society]. St. Petersburg: Yzd-vo «SPbGPU» [in Russian].

8. Nazarchuk, A.V. (2008). Setevoe obshchestvo i ego filosofskoe osmyslenie [Network society and its philosophical comprehension]. Voprosy filosofii, 7, 61-75 [in Russian].

9. Rating of popular sites for April 2018. Retrieved from: https://nsua.com/news/ reyting-populyarnih-saytiv-zakviten-2018 [in Ukrainian].

10. Rozin, V.M. Ponyatie $i$ sovremennye kontseptsii tekhniki [Concept and modern concepts of technology]. Moscow: Yzd-vo «IFRAN». Retrieved from: https://iphras.ru/uplfile/root/biblio/ 2006/Rozin_1.pdf [in Russian].

11. Rouz, R. (2002). Dostizhenie tseley v kvazisovremennom obshchestve: sotsialnye seti v Rossii [Achievement of goals in a quasi-modern society: social networks in Russia]. Obshchestvennye nauki i sovremennost, 3, 23-38 [in Russian].

12. Sazonov, V.M. Sotsialnye seti - analiz i perspektivy [Social networks - analysis and prospects]. Retrieved from: http://spkurdyumov.ru/biology/socialnye-seti-analiz-i-perspektivy/ [in Russian].

13. Sazonov, V.M. (2010). Sotsialno-setevye tekhnologii. Sistemnyy analiz.i prognoz [Socio-network technologies. System analysis. and forecast]. Moscow: Yzd-vo « Laboratoriya SVM» [in Russian].

14. Simonov, P.V. (1993). Sozidayushchiy mozg: neyrobiologicheskie osnovy tvorchestva [The creative brain: the neurobiological basis of creativity]. Moscow: Yzd-vo « Nauka» [in Russian].

15. Yakimchuk, O. (2012). Agenti sotsialnikh peretvoren ta prichini rozvitku onlaynovikh sotsialnikh struktur [Agents sotsialnih peredvoren that cause rozvitku online social structures]. Religiya ta sotsium, 2, 178 -184 [in Ukrainian].

\section{Дідик Лучезара Анатоліївна}

Аспірантка кафедри соціології

Національного педагогічного університету імені М. П. Драгоманова

01601, м. Київ, вул. Пирогова, 9

\section{Didyk Luchezara}

Postgraduate student of the Department of Sociology

National Pedagogical Dragomanov University

9, Pyrohova St., 01601, Kyiv, Ukraine

ORCID: 0000-0003-2117-3827_Email: luchezara.88@gmail.com

Цитування: Дідик Л. А. Просторова диспозиція агентів комунікації в соціальних мережах / Л. А. Дідик // Науково-теоретичний альманах «Грані». - 2018. - Т. 21. - № 6. - С. 51-58.

Citation: Didyk, L.A. (2018). Prostorova dyspozytsiia ahentiv komunikatsii v sotsialnykh merezhakh [Spatial disposition of agents of communication in social networks]. Scientific and theoretical almanac «Grani», 21(6), 51-58. 